Article

\title{
Optimal Nitrogen Application Rates of One-Time Root Zone Fertilization and the Effect of Reducing Nitrogen Application on Summer Maize
}

\author{
Chaoqiang Jiang ${ }^{1,2, *,+}$, Xuexiang Ren ${ }^{3, \dagger}$, Huoyan Wang ${ }^{2}$, Dianjun $\mathrm{Lu}^{2}$, Chaolong $\mathrm{Zu}^{1}$ and \\ Shiji Wang ${ }^{1}$ \\ 1 Tobacco Research Institute/Maize Research Center, Anhui Academy of Agricultural Sciences, Hefei 230031, \\ China; 1cz2468@163.com (C.Z.); wangymzx@163.com (S.W.) \\ 2 State Key Laboratory of Soil and Sustainable Agriculture, Institute of Soil Science, Chinese Academy of \\ Sciences, Nanjing 210008, China; hywang@issas.ac.cn (H.W.); djlu@issas.ac.cn (D.L.) \\ 3 Institute of Plant Protection and Agro-products Safety, Anhui Academy of Agricultural Sciences, \\ Hefei 230031, China; rxxiang@sina.com \\ * Correspondence: chaoqjiang@163.com; Tel.: +86-551-6514-8998 \\ + These authors contributed equally to this work.
}

Received: 16 April 2019; Accepted: 21 May 2019; Published: 25 May 2019

\begin{abstract}
Improvement in fertilization methods, including the optimal matching of nutrient supply and root nutrient absorption by applying nitrogen $(\mathrm{N})$ in the root zone of crop, is necessary to improve $\mathrm{N}$ use efficiency (NUE), maintain high stable yield cultivation of maize, and contribute toward future environmental protection. The current practice of split surface broadcasting (SSB) of $\mathrm{N}$ is labor-intensive and the surface broadcasting causes a large amount of $\mathrm{N}$ to leach into the environment, yet it does not substantially increase maize yield. Root zone fertilization (RZF) has been identified as an efficient way to solve such problems. However, information on the appropriate amount of $\mathrm{N}$ fertilizer under RZF for summer maize remains limited. Therefore, in this study, a two-year consecutive field experiment was conducted during 2015-2016 in Anhui province, China, to investigate the effect of $\mathrm{N}$ rate and application method on grain yield, nutrient uptake, and NUE of summer maize. The method chosen is not only important to increase grain yield but also critical for reducing $\mathrm{N}$ rate and potential loss in the maize cropping system. The experiment comprised six $\mathrm{N}$ rates $\left(90,135,180,225,270\right.$, and $360 \mathrm{~kg} \mathrm{~N} \mathrm{hm}^{-2}$ ) and two $\mathrm{N}$ application methods in both 2015 and 2016. The two N application methods included SSB and one-time RZF. Results showed that grain yield of summer maize increased first and then decreased with the increase of $\mathrm{N}$ rate; however, when the $\mathrm{N}$ rate increased to $270 \mathrm{~kg} \mathrm{hm}^{-2}$, the grain yield increased slowly or even decreased. Compared with SSB, RZF increased grain yield by $4 \%$, and the effect of $\mathrm{N}$ on grain yield was mainly related to the number of kernels per ear and 1000-seed weight. One-time RZF increased N apparent recovery efficiency by $18 \%$ (7.2 percentage points) compared with SSB and also improved the $\mathrm{N}$ agronomic efficiency, $\mathrm{N}$ physiological efficiency, and $\mathrm{N}$ partial factor productivity. In the comprehensive consideration of yield target, NUE, and soil $\mathrm{N}$ balance, the optimal $\mathrm{N}$ rate for summer maize in the vertisol soil of Anhui province was $180-225 \mathrm{~kg} \mathrm{hm}^{-2}$ for one-time RZF, which reduced $\mathrm{N}$ fertilizer by $14 \%$ compared with the SSB. Overall, one-time RZF has great potential for green and sustainable agriculture, and thus fertilization machines are worthy of development and application in maize cropping systems.
\end{abstract}

Keywords: summer maize; nitrogen fertilizer; one-time fertilization; root zone fertilization; $\mathrm{N}$ use efficiency 


\section{Introduction}

Nitrogen $(\mathrm{N})$ fertilizer plays an important role in ensuring crop yield increase and food security [1]. Crop yield increases with the increase of $\mathrm{N}$ fertilizer application; however, when $\mathrm{N}$ application rate exceeds a certain range, crop yield does not continue to increase, or even has a downward trend, and the $\mathrm{N}$ loss significantly increases, resulting in serious resource waste and environmental pollution $[1,2]$. Excessive application of $\mathrm{N}$ fertilizer is common in maize production in China, especially in areas with a high degree of agricultural intensive production. For example, application to high-yield maize fields in Shandong province can reach $249 \mathrm{~kg} \mathrm{hm}^{-2}$, and the average $\mathrm{N}$ application in the North China Plain even reached $360 \mathrm{~kg} \mathrm{hm}^{-2}$ [3], which is far higher than the recommended $\mathrm{N}$ application rate of $180 \mathrm{~kg} \mathrm{hm}^{-2}$ [4]. The target yield of summer maize in middle-high yield fields of the Huang-Huai-Hai Plain is $7500-9000 \mathrm{~kg} \mathrm{hm}^{-2}$, and the recommended amount of $\mathrm{N}$ fertilizer is $180-210 \mathrm{~kg} \mathrm{hm}^{-2}$. However, the amount of $\mathrm{N}$ fertilizer used in the current maize season far exceeds this level [5]. In the vertisol soil of Anhui province, the $\mathrm{N}$ application amount of maize in regular stages reached $310 \mathrm{~kg} \mathrm{hm}^{-2}$, and the $\mathrm{N}$ use efficiency (NUE) was only about 23\% [6]. Therefore, how to reduce the amount of $\mathrm{N}$ fertilizer and improve the NUE while ensuring high and stable yield remains a major issue in China.

Split application is the traditional fertilization method for maize, but with the increase of labor cost, the development of controlled release fertilizer, and the promotion of mechanized fertilization, one-time fertilization is expected to be the development direction and inevitable trend for maize fertilization $[7,8]$. One-time fertilization means that all the fertilizers were just applied one time during the whole growth period of a crop $[9,10]$. One-time application in the entire fertilization stage could change the traditional broadcast method of fertilization. Recently, the "mechanism and approach of sustainable and efficient utilization of fertilizer nutrients" project explicitly pointed out that root zone fertilization (RZF) is an important means to considerably improve the utilization ratio of $\mathrm{N}$ fertilizer, and one-time RZF was found to be an optimal fertilization approach to increase rice yield [11,12], maize yield [8,13], and NUE [12,13]. Our latest research demonstrated the suitability of one-time fertilization in the root area of maize [14] and also confirmed the role of one-time RZF in ensuring a high and stable yield of maize $[8,13]$. However, it remains unclear whether one-time RZF can reduce the rate of $\mathrm{N}$ and what is the optimal range of $\mathrm{N}$ application for summer maize.

It is of great importance to identify an appropriate amount of $\mathrm{N}$ fertilizer that takes into account both crop yield and environmental effects. Therefore, to understand the effect of $\mathrm{N}$ application rate on grain yield and NUE of summer maize under one-time RZF, a local maize variety "Longping 206" was selected and planted in Taihe county, Anhui province, China. This study aimed to confirm the one-time $\mathrm{N}$ application method for achieving high yield in maize and to achieve an optimal $\mathrm{N}$ rate for summer maize in the Huang-Huai-Hai Plain of China. These findings will provide theoretical basis and technical support for scientific and reasonable $\mathrm{N}$ application and reduction and increase the efficiency of $\mathrm{N}$ application in maize.

\section{Material and Methods}

\subsection{Experimental Site and Growth Conditions}

The experiment was carried out in Taihe county $\left(33^{\circ} 15^{\prime} \mathrm{N}, 115^{\circ} 36^{\prime} \mathrm{E}\right)$, Anhui province, located on the Huang-Huai-Hai Plain, one of the largest maize zones in China. The experimental soil is classified as vertisol according to FAO/ISRIC classification systems. The topsoil $(0-20 \mathrm{~cm})$ has a $\mathrm{pH}$ of 8.1, $19.2 \mathrm{~g} \mathrm{~kg}^{-1}$ organic matter, $1.38 \mathrm{~g} \mathrm{~kg}^{-1}$ total $\mathrm{N}, 92.1 \mathrm{mg} \mathrm{kg}^{-1}$ available $\mathrm{N}, 23.5 \mathrm{mg} \mathrm{kg}^{-1}$ available $\mathrm{P}$, and $235.3 \mathrm{mg} \mathrm{kg}^{-1}$ available $\mathrm{K}$. The rainfall and temperature during the experiment period (from May to October) were described by Jiang et al. [13].

\subsection{Experiment Design and Field Management}

The experiment included two $\mathrm{N}$ application methods (conventional two-split surface broadcasting (SSB) and one-time RZF), and six N fertilizer rates (90, 135, 180, 225, 270, and $360 \mathrm{~kg} \mathrm{hm}^{-2}$ ). Therefore, 
13 treatments (two application methods $\times$ six $\mathrm{N}$ rates, plus a control without $\mathrm{N}$ fertilizer treatment (CK)) were carried out for the experiment in both 2015 and 2016. A randomized complete block design with three replicates was used. The area of the plot was $2.4 \mathrm{~m} \times 2.8 \mathrm{~m}$ in 2015 (4 rows, 10 plants in each row) and $3.0 \mathrm{~m} \times 5.6 \mathrm{~m}$ in 2016 (5 rows, 20 plants in each row). Each plot was separated from the adjacent plot by $30 \mathrm{~cm}$-wide earthen banks. The N, P, and $\mathrm{K}$ fertilizer was applied as urea (N $46 \%)$, superphosphate $\left(\mathrm{P}_{2} \mathrm{O}_{5} 16 \%\right)$, and potassium chloride $\left(\mathrm{K}_{2} \mathrm{O} 60 \%\right)$ via the SSB and RZF fertilization methods, respectively. All the urea for RZF was applied on 17 June and 15 June in 2015 and 2016, respectively. While for SSB, 50\% of the total urea was applied on 17 June and $15 \mathrm{June}$, and $50 \%$ urea was applied for the second time on 2 August and 1 August in 2015 and 2016, respectively. The amount and application methods of the $\mathrm{P}$ and $\mathrm{K}$ fertilizer were the same as used by Jiang et al. [8]. The local suitable variety "Longping 206" was selected as the maize variety, with row spacing of $60 \mathrm{~cm} \times 28 \mathrm{~cm}$ and density of 60,000 plants $\mathrm{hm}^{-2}$. In addition to the application of $\mathrm{N}$ fertilizer, other field management methods were in accordance with local conventional measures. In 2015, maize was sown on 17 June and harvested on 27 September. In 2016, it was sown on 15 June and harvested on 25 September.

\subsection{Sampling and Measurements}

At harvest, the number of ears per plot was determined, and the grain yield and biomass were also determined by harvesting all plants in each plot. The grain characteristics including grain number per ear and 1000-seed weight were measured by adjusting kernels to $14 \%$ moisture content. The plants were divided into two parts (straw and grain) for drying to constant weight at $70{ }^{\circ} \mathrm{C}$, before being ground to powder and passed through a $0.15-\mathrm{mm}$ screen for $\mathrm{N}$ content analysis. Total $\mathrm{N}$ concentration was determined by the method described by Jiang et al. [13].

\subsection{Calculation Methods}

The $\mathrm{N}$ accumulation, $\mathrm{N}$ agronomic efficiency (NAE), N physiological efficiency (NPE), N partial factor productivity (NPFP), and N apparent recovery efficiency (NARE) were calculated according to the methods of López-Bellido et al. [15] and Jiang et al. [16].

\subsection{Statistical Analysis}

Data calculation and figures mapping were performed using Microsoft Excel 2013. Two-way analysis of variance was used to assess the effects of $\mathrm{N}$ application method and $\mathrm{N}$ rate in SPSS 13.0 (SPSS Inc., Chicago, IL, USA). The means of the treatments were compared using the least significance difference test at $p<0.05$.

\section{Results}

\subsection{Grain Yield and Its Components}

As shown in Figure 1, the grain yield of maize varied between 8.7 and $13.0 \mathrm{Mg} \mathrm{hm}^{-2}$ for N application treatments, which was on average $41.7 \%$ and 30.5\% higher than that of CK in 2015 and 2016, respectively. The results for the two years showed that the grain yield of maize increased as the $\mathrm{N}$ rate increased, but after the $\mathrm{N}$ rate reached $225 \mathrm{~kg} \mathrm{hm}^{-2}$, the increase of yield significantly decreased, or there was no trend of increase in grain yield. Overall, under the same $\mathrm{N}$ application rate, the grain yield of RZF was slightly higher than that of SSB.

According to the relationship between grain yield $(y)$ and $\mathrm{N}$ rate $(x)$ under different treatments, a simple quadratic regression equation $\left(y=a x^{2}+b x+c\right)$ was established to describe the change of grain yield with $\mathrm{N}$ rate (Figure 1). As shown in Table 1, it was calculated that the $\mathrm{N}$ application rate in the 2015 and 2016 for the maximum yield of SSB and RZF was $320.7-361.2$ and $275.8-309.7 \mathrm{~kg} \mathrm{hm}^{-2}$, respectively, and the corresponding grain yield was $12.8-13.0$ and $13.0-13.1 \mathrm{Mg} \mathrm{hm}^{-2}$, respectively, according to the regression equation. Based on the price of maize grain and $\mathrm{N}$ fertilizer, it was calculated that the optimal economic rate of N fertilizer in the 2015 and 2016 applied for SSB and RZF was 307.8-344.5 
and $266.5-297.3 \mathrm{~kg} \mathrm{hm}^{-2}$, respectively. The $\mathrm{N}$ fertilizer for RZF could be reduced by $14 \%$ compared with SSB to achieve an optimal yield. The two years of results showed that the maximum yield and the optimal yield of RZF were both higher than those of fractional fertilization.
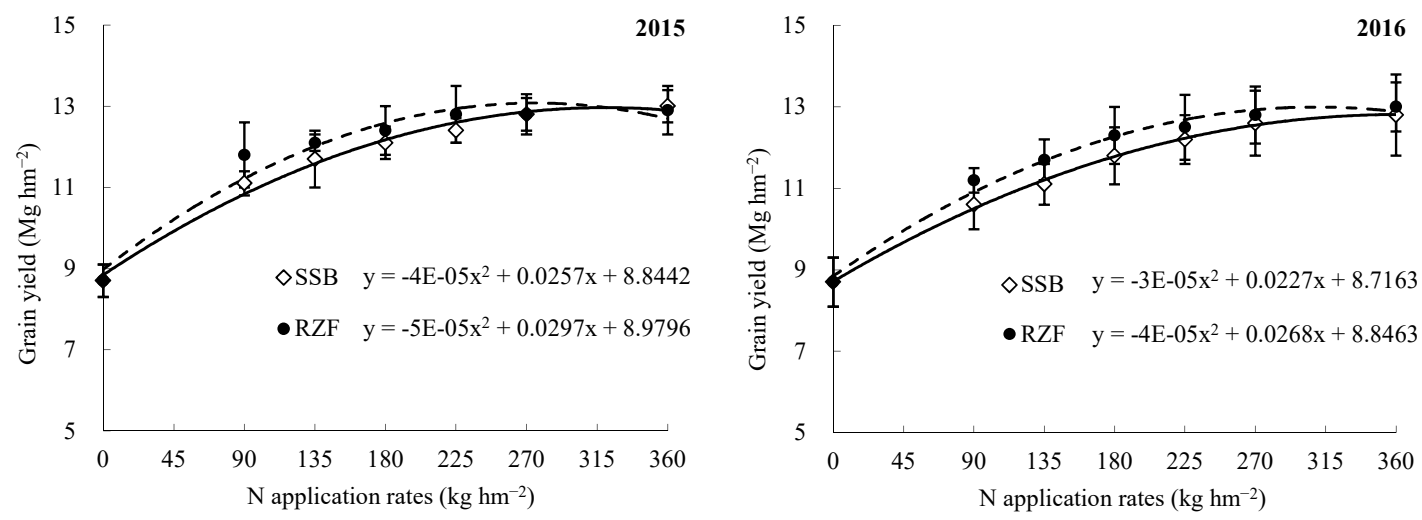

Figure 1. Effect of $\mathrm{N}$ rate and application method on grain yield of summer maize. Data are the means of three replicates.

Table 1. $\mathrm{N}$ application rate for maximum and optimum yield of summer maize under different $\mathrm{N}$ application method.

\begin{tabular}{|c|c|c|c|c|c|}
\hline Year & $\begin{array}{l}\text { N Application } \\
\text { Method }\end{array}$ & $\begin{array}{l}\text { Maximum Yield N } \\
\text { Rate }\left(\mathrm{kg} \mathrm{hm}^{-2}\right)\end{array}$ & $\begin{array}{l}\text { Maximum Yield } \\
\left(\mathrm{Mg} \mathrm{hm}^{-2}\right)\end{array}$ & $\begin{array}{l}\text { Optimum Economic } \\
\text { N Rate }\left(\mathrm{kg} \mathrm{hm}^{-2}\right)\end{array}$ & $\begin{array}{l}\text { Optimum Yield } \\
\left(\mathrm{Mg} \mathrm{hm}^{-2}\right)\end{array}$ \\
\hline \multirow{2}{*}{2015} & SSB & 320.7 & 12.97 & 307.8 & 12.96 \\
\hline & RZF & 275.8 & 13.08 & 266.5 & 13.07 \\
\hline \multirow{2}{*}{2016} & SSB & 361.2 & 12.81 & 344.5 & 12.80 \\
\hline & RZF & 309.7 & 13.00 & 297.3 & 12.99 \\
\hline
\end{tabular}

Among all the treatments, the lowest ear number per hectare at harvest was found in CK, and there was no significant difference between the $\mathrm{N}$ application treatments (Table 2). The $\mathrm{N}$ application treatments significantly increased the kernel number per ear of maize by $13.6-34.9 \%$ compared with CK (441.1-452.5). The kernel number per ear increased with the increase of the $\mathrm{N}$ rate but decreased when the $\mathrm{N}$ rate exceeded $270 \mathrm{~kg} \mathrm{hm}^{-2}$. The RZF achieved a slightly higher -kernel number per ear than the SSB under the same N application rate. The 1000-seed weight of the CK treatment was 283.1-288.7 $\mathrm{g}$, which was significantly lower than that of the $\mathrm{N}$ application treatments. There was no significant difference in 1000-seed weight when the $\mathrm{N}$ application rate was between 135 and $360 \mathrm{~kg} \mathrm{hm}^{-2}$.

Table 2. Effect of $\mathrm{N}$ rate and application method on Yield components of summer maize.

\begin{tabular}{|c|c|c|c|c|c|c|c|}
\hline \multirow{2}{*}{$\begin{array}{l}\text { N Rate } \\
\left(\mathrm{kg} \mathrm{hm}^{-2}\right)\end{array}$} & \multirow{2}{*}{$\begin{array}{c}\text { N Application } \\
\text { Method }\end{array}$} & \multicolumn{3}{|c|}{2015} & \multicolumn{3}{|c|}{2016} \\
\hline & & $\begin{array}{l}\text { Ear Numbers } \\
(\text { ear hm-2) }\end{array}$ & $\begin{array}{l}\text { Kernels } \\
\text { per Ear }\end{array}$ & $\begin{array}{l}\text { 1000-Seed } \\
\text { Weight (g) }\end{array}$ & $\begin{array}{l}\text { Ear Numbers } \\
(\text { ear hm-2) }\end{array}$ & $\begin{array}{l}\text { Kernels } \\
\text { per Ear }\end{array}$ & $\begin{array}{l}\text { 1000-Seed } \\
\text { Weight (g) }\end{array}$ \\
\hline 0 & CK & $58,500 \mathrm{~b}$ & $441.3 \mathrm{e}$ & 288.7 c & $58,350 \mathrm{~b}$ & $452.5 \mathrm{f}$ & $283.1 \mathrm{c}$ \\
\hline 90 & \multirow{6}{*}{ SSB } & $58,875 \mathrm{ab}$ & $508.0 \mathrm{~d}$ & $315.7 b$ & $58,950 \mathrm{ab}$ & $514.0 \mathrm{e}$ & $311.1 \mathrm{~b}$ \\
\hline 135 & & $58,875 \mathrm{ab}$ & $527.3 \mathrm{~d}$ & $322.0 \mathrm{ab}$ & $58,950 \mathrm{ab}$ & $536.5 \mathrm{de}$ & $316.3 \mathrm{ab}$ \\
\hline 180 & & $59,250 \mathrm{ab}$ & $546.0 \mathrm{bcd}$ & $325.5 \mathrm{ab}$ & $59,100 \mathrm{ab}$ & 553.5 bcde & $320.4 \mathrm{ab}$ \\
\hline 225 & & $58,875 \mathrm{ab}$ & $581.3 \mathrm{abc}$ & $322.8 \mathrm{ab}$ & $58,800 \mathrm{ab}$ & $572.5 \mathrm{abcd}$ & $327.7 \mathrm{a}$ \\
\hline 270 & & 59,625 a & $592.0 \mathrm{ab}$ & $321.8 \mathrm{ab}$ & $59,250 \mathrm{ab}$ & $592.5 \mathrm{ab}$ & $317.8 \mathrm{ab}$ \\
\hline 360 & & $58,875 \mathrm{ab}$ & $586.7 \mathrm{ab}$ & $320.9 \mathrm{ab}$ & $59,100 \mathrm{ab}$ & $588.0 \mathrm{abc}$ & $318.7 \mathrm{ab}$ \\
\hline 90 & \multirow{6}{*}{$\mathrm{RZF}$} & $58,875 \mathrm{ab}$ & $538.7 \mathrm{~cd}$ & $327.9 \mathrm{ab}$ & $58,800 \mathrm{ab}$ & $529.5 \mathrm{de}$ & $318.5 \mathrm{ab}$ \\
\hline 135 & & $58,875 \mathrm{ab}$ & $544.5 \mathrm{bcd}$ & $328.5 \mathrm{ab}$ & $59,100 \mathrm{ab}$ & 545.0 cde & $320.4 \mathrm{ab}$ \\
\hline 180 & & $59,250 \mathrm{ab}$ & $575.3 \mathrm{abc}$ & $331.7 \mathrm{ab}$ & $59,400 \mathrm{ab}$ & $571.0 \mathrm{abcd}$ & $316.4 \mathrm{ab}$ \\
\hline 225 & & $59,250 \mathrm{ab}$ & $586.7 \mathrm{ab}$ & $329.8 \mathrm{ab}$ & $58,950 \mathrm{ab}$ & $588.0 \mathrm{abc}$ & $324.3 \mathrm{ab}$ \\
\hline 270 & & 59,625 a & $590.0 \mathrm{ab}$ & $336.1 \mathrm{a}$ & $59,100 \mathrm{ab}$ & $600.0 \mathrm{a}$ & $320.0 \mathrm{ab}$ \\
\hline 360 & & 59,625 a & $595.3 \mathrm{a}$ & $327.0 \mathrm{ab}$ & 59,550 a & $604.0 \mathrm{a}$ & $316.7 \mathrm{ab}$ \\
\hline
\end{tabular}

Note: Within columns, values followed by different lowercase letters indicate a significant difference $(p<0.05)$. 


\subsection{Dry Matter Accumulation}

The aboveground dry weight of maize plants for all treatments was $14.0-20.4 \mathrm{Mg} \mathrm{hm}^{-2}$, which was lowest in CK for both 2015 and 2016 (Figure 2). The N application treatments significantly increased the aboveground dry weight by $12.9-42.1 \%$ compared with CK. With the increase of $\mathrm{N}$ application rate, the aboveground dry weight showed a gradually increasing trend in both SSB and RZF. The two years of results showed that the aboveground dry weight of RZF was slightly higher than that of SSB under the same $\mathrm{N}$ application rate.
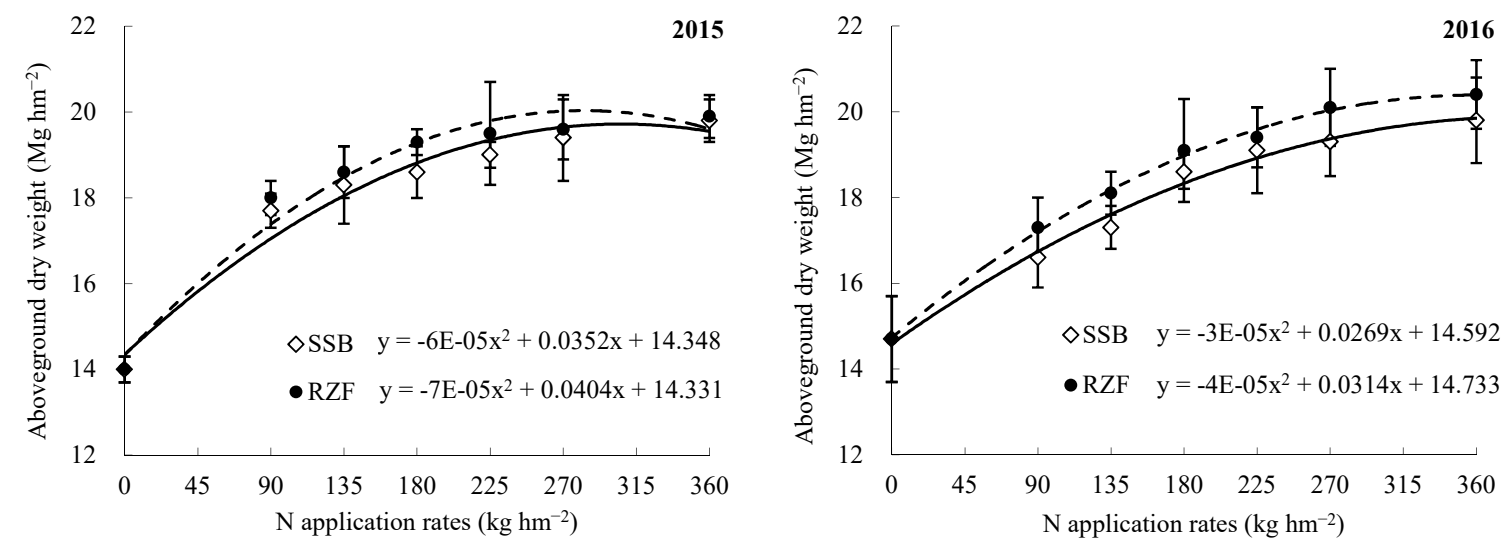

Figure 2. Effect of $\mathrm{N}$ rate and application method on aboveground dry weight of summer maize.

Data were the means of three replicates.

\subsection{Nitrogen Concentration and Accumulation}

As shown in Table 3, $\mathrm{N}$ concentration was between 11.4 and $13.1 \mathrm{~g} \mathrm{~kg}^{-1}$ in grain and between 10.9 and $11.7 \mathrm{~g} \mathrm{~kg}^{-1}$ in straw under $\mathrm{CK}$, whereas it was between 12.5 and $15.1 \mathrm{~g} \mathrm{~kg}^{-1}$ and between 11.8 and $14.5 \mathrm{~g} \mathrm{~kg}^{-1}$ under the $\mathrm{N}$ application treatments, respectively. The $\mathrm{N}$ concentration for $\mathrm{CK}$ was the lowest in both grain and straw. With the increase of $\mathrm{N}$ application rate, the $\mathrm{N}$ concentration in both grain and straw showed an increasing trend. The results for the two years showed that under the same $\mathrm{N}$ application rate, the $\mathrm{N}$ concentration in grain and straw of RZF was slightly higher than that of SSB.

Table 3. Effect of $\mathrm{N}$ rate and application method on $\mathrm{N}$ concentration and accumulation of summer maize.

\begin{tabular}{|c|c|c|c|c|c|c|c|}
\hline \multirow[b]{2}{*}{$\begin{array}{l}\text { N Rate } \\
\left(\mathrm{kg} \mathrm{hm}^{-2}\right)\end{array}$} & \multirow[b]{2}{*}{$\begin{array}{c}\text { N Application } \\
\text { Method }\end{array}$} & \multicolumn{3}{|c|}{2015} & \multicolumn{3}{|c|}{2016} \\
\hline & & $\begin{array}{c}\mathrm{N} \\
\text { Concentration } \\
\text { in Grain } \\
\left(\mathrm{g} \mathrm{kg}^{-1}\right)\end{array}$ & $\begin{array}{c}\mathrm{N} \\
\text { Concentration } \\
\text { in Straw } \\
\left(\mathrm{g} \mathrm{kg}^{-1}\right)\end{array}$ & $\begin{array}{l}\text { N Uptake in } \\
\text { Whole Plant } \\
\left(\mathrm{kg} \mathrm{hm}^{-2}\right)\end{array}$ & $\begin{array}{c}\mathrm{N} \\
\text { Concentration } \\
\text { in Grain } \\
\left(\mathrm{g} \mathrm{kg}^{-1}\right)\end{array}$ & $\begin{array}{c}\mathrm{N} \\
\text { Concentration } \\
\text { in Straw } \\
\left(\mathrm{g} \mathrm{kg}^{-1}\right)\end{array}$ & $\begin{array}{c}\text { N Uptake in } \\
\text { Whole Plant } \\
\left(\mathrm{kg} \mathrm{hm}^{-2}\right)\end{array}$ \\
\hline 0 & & $11.4 \mathrm{e}$ & $10.9 \mathrm{e}$ & $147.8 \mathrm{~g}$ & $13.1 \mathrm{c}$ & $11.7 \mathrm{~d}$ & $181.4 \mathrm{f}$ \\
\hline 90 & \multirow{6}{*}{ SSB } & $12.5 \mathrm{de}$ & $11.8 \mathrm{de}$ & $203.6 \mathrm{f}$ & $14.1 \mathrm{~b}$ & $12.9 \mathrm{bc}$ & $220.5 \mathrm{e}$ \\
\hline 135 & & $12.8 \mathrm{bcd}$ & $12.2 \mathrm{cde}$ & 217.7 ef & $14.7 \mathrm{ab}$ & $13.4 \mathrm{abc}$ & 244.5 cde \\
\hline 180 & & $13.1 \mathrm{bcd}$ & $12.4 \mathrm{~cd}$ & 230.2 de & $14.8 \mathrm{ab}$ & $13.6 \mathrm{abc}$ & $258.7 \mathrm{bcd}$ \\
\hline 225 & & $13.4 \mathrm{abcd}$ & $13.0 \mathrm{bcd}$ & $242.9 \mathrm{~cd}$ & $14.7 \mathrm{ab}$ & $13.5 \mathrm{abc}$ & $268.5 \mathrm{bc}$ \\
\hline 270 & & $13.6 \mathrm{abcd}$ & $13.0 \mathrm{bcd}$ & $255.9 \mathrm{bc}$ & $14.8 \mathrm{ab}$ & $13.6 \mathrm{abc}$ & $274.5 \mathrm{abc}$ \\
\hline 360 & & $14.0 \mathrm{abc}$ & $14.0 \mathrm{ab}$ & $282.0 \mathrm{a}$ & $14.8 \mathrm{ab}$ & $14.1 \mathrm{ab}$ & $285.6 \mathrm{ab}$ \\
\hline 90 & \multirow{6}{*}{ RZF } & $12.6 \mathrm{cde}$ & $12.1 \mathrm{cde}$ & $209.9 \mathrm{f}$ & $14.4 \mathrm{ab}$ & $12.8 \mathrm{bc}$ & $235.7 \mathrm{de}$ \\
\hline 135 & & $13.4 \mathrm{abcd}$ & $12.6 \mathrm{~cd}$ & $230.1 \mathrm{de}$ & $14.7 \mathrm{ab}$ & $13.7 \mathrm{abc}$ & $254.5 \mathrm{~cd}$ \\
\hline 180 & & $13.9 \mathrm{abcd}$ & $12.6 \mathrm{~cd}$ & $244.7 \mathrm{~cd}$ & $14.9 \mathrm{ab}$ & $13.8 \mathrm{abc}$ & $271.6 \mathrm{bc}$ \\
\hline 225 & & $14.6 \mathrm{a}$ & $13.0 \mathrm{bcd}$ & $268.9 \mathrm{ab}$ & $14.9 \mathrm{ab}$ & $13.8 \mathrm{abc}$ & $271.8 \mathrm{bc}$ \\
\hline 270 & & $14.1 \mathrm{ab}$ & $13.4 \mathrm{abc}$ & $272.7 \mathrm{ab}$ & $14.9 \mathrm{ab}$ & $13.7 \mathrm{abc}$ & $285.2 \mathrm{ab}$ \\
\hline 360 & & $13.7 \mathrm{abcd}$ & $14.5 \mathrm{ab}$ & $284.0 \mathrm{a}$ & $15.1 \mathrm{a}$ & $14.5 \mathrm{a}$ & $303.0 \mathrm{a}$ \\
\hline
\end{tabular}

Note: Within columns, values followed by different lowercase letters indicate a significant difference $(p<0.05)$.

The $\mathrm{N}$ uptake in the whole plant varied between 147.8 and $181.4 \mathrm{~kg} \mathrm{hm}^{-2}$ in the CK and between 203.6 and $303.0 \mathrm{~kg} \mathrm{hm}^{-2}$ in the $\mathrm{N}$ application treatments, respectively. Nitrogen application significantly increased the $\mathrm{N}$ uptake in the whole plant, and the $\mathrm{N}$ uptake increased with the increase of $\mathrm{N}$ application 
rate. In general, the $\mathrm{N}$ uptake in the whole plant of RZF was higher than that of SSB under the same $\mathrm{N}$ application rate (Table 3).

\subsection{Nitrogen Use Efficiency}

The effect of N application rate and method on NUE of summer maize for 2015-2016 was showed in Table 4. The NAE of maize varied between 11.5 and $34.2 \mathrm{~kg} \mathrm{~kg}^{-1}$ under the different $\mathrm{N}$ application rates. The highest NAE ( $34.2 \mathrm{~kg} \mathrm{~kg}^{-1}$ ) was found in RZF with the $\mathrm{N}$ rate of $90 \mathrm{~kg} \mathrm{hm}^{-2}$. The NAE decreased gradually with the increase of $\mathrm{N}$ application rate. Similarly, the results for the two-year period showed that the NPE, NPFP, and NARE were significantly affected by both the N application rate and method. The NPE, NPFP, and NARE for all N application treatments were $32.4-46.8 \mathrm{~kg} \mathrm{~kg}^{-1}$, $25.6-131.0 \mathrm{~kg} \mathrm{~kg}^{-1}$, and $29.9-60.4 \%$, respectively, and all indexes showed a gradual decline with the increase of the N application rate. However, a higher NARE was found in RZF treatments than in SSB treatments, especially under the low and medium levels of $\mathrm{N}$ application $\left(90-180 \mathrm{~kg} \mathrm{hm}^{-2}\right)$. Under the $\mathrm{N}$ application of $90 \mathrm{~kg} \mathrm{hm}^{-2}$, RZF obtained the highest NARE, which was $59.1 \%$ and $60.4 \%$ in 2015 and 2016, respectively. Overall, the NARE of all RZF treatments was $18 \%$ ( 7.2 percentage points) higher than that of SSB.

Table 4. Effect of $\mathrm{N}$ rate and application method on $\mathrm{N}$ use efficiency of summer maize.

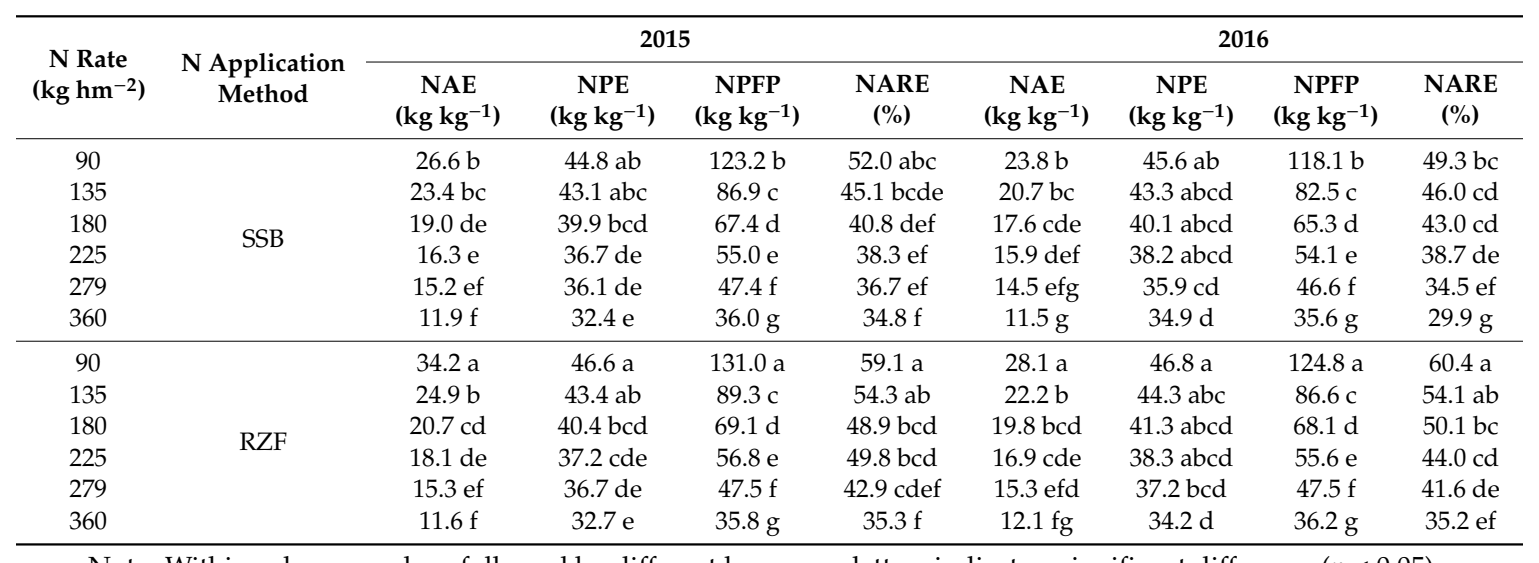

Note: Within columns, values followed by different lowercase letters indicate a significant difference $(p<0.05)$.

\section{Discussion}

\subsection{Effect of RZF on Grain Yield and Yield Components}

This study showed that under the same rate of $\mathrm{N}$ application, RZF increased the grain yield by $4 \%$ compared with SSB (Figure 1), indicating that the one-time application of urea also achieved high yield. As an optimized one-time N fertilization, RZF could achieve the goal of crop yield increase. Because the one-time fertilization requires less labor than conventional applications and achieves strong benefits as split application, it has gradually become a widely implemented fertilization technique $[10,17,18]$. Some studies have also confirmed that only one-time fertilization during a given growth period can achieve high yield and improve fertilizer use efficiency than SSB $[7,9,17,18]$. However, research on the one-time application of $\mathrm{N}$ fertilizer has mainly focused on controlled-release fertilizer and has paid little attention to the one-time application of common urea. In this study, one-time RZF with common urea was found to achieve a high grain yield and even obtained higher yield than the current fertilization method (SSB) under the same rate of urea application.

One-time RZF of urea could increase yield, which may be because RZF allowed the $\mathrm{N}$ fertilizer to be distributed in the area of the active root system, and the dynamic range of $\mathrm{N}$ fertilizer nutrient diffusion thus better matched the dynamic range of root system extension, therefore promoting the absorption of $\mathrm{N}$ by the root system [19]. Moreover, RZF significantly increased $\mathrm{N}$ concentration and prolonged the supply time of $\mathrm{N}$ in the soil, realizing the continuous supply of high $\mathrm{N}$ to meet the 
needs of maize for 90 days $[13,14]$. Previous studies reported that, combined with deep-application technology, the RZF significantly increased the concentration of $\mathrm{NH}_{4}{ }^{+}-\mathrm{N}$ in the root area of crops and prolonged the $\mathrm{N}$-supply period $[11,20,21]$. In areas of high $\mathrm{N}$ supply, such as $\mathrm{N}$ patches, the proliferation of the root system increased substantially, thereby improving the nutrient absorbability of roots and increasing the crop yield [20,22]. Therefore, this study confirmed that there is great potential for improving crop yield by optimizing fertilizer placement. However, the effects of one-time RZF of urea on high and stable yield of crops in different areas and soil types still need to be further discussed and demonstrated for popularization and application.

Nitrogen affects crop yield mainly by adjusting ear numbers, kernels per ear, and 1000-seed weight. Previous studies have shown that, within a certain extent of $\mathrm{N}$ application rate, the number of kernels per ear increase with the increasing $\mathrm{N}$ rate; however, the kernels per ear did not increase or even decrease under the overuse of $\mathrm{N}$ fertilizers [23,24]. Some studies have suggested that the effect of yield components on maize yield decreased in the following order: ear numbers per area > kernels per ear $>1000$-seed weight $[25,26]$. In this study, it was found that when the planting density was 60,000 plants $\mathrm{hm}^{-2}$, the number of kernels per ear increased with the increasing $\mathrm{N}$ rate from 90 to $270 \mathrm{~kg} \mathrm{hm}^{-2}$, whereas it decreased when the $\mathrm{N}$ rate exceeded $270 \mathrm{~kg} \mathrm{hm}^{-2}$. Cao et al. [24] found that the grain yield of summer maize was mainly affected by the number of kernels per ear in the Huang-Huai-Hai Plain of China. Cai et al. [27] reported that the difference in grain yield of spring maize was mainly caused by the number of kernels per ear and 1000-seed weight at the middle of northeast China. In this study, it was concluded that $\mathrm{N}$ rate affected the grain yield of summer maize mainly by influencing the kernels per ear and 1000-seed weight in both the RZF and SSB.

\subsection{Effect of RZF on Nitrogen Use Efficiency}

In this study, it was found that RZF could improve the NUE of summer maize. Under the same rate of N application, the NARE of RZF was 7.2 percentage points higher than that of SSB, and the NAE, NPE, and NPFP of RZF were also higher than those of SSB. Many studies have focused on the effects of $\mathrm{N}$ rate and application method on NUE of summer maize $[7,14,18]$. The utilization efficiency of $\mathrm{N}$ fertilizer varied greatly due to the significant influence of soil properties, $\mathrm{N}$ fertilizer types, application techniques, and meteorological conditions. The apparent recovery efficiency (ARE), agronomic efficiency (AE), physiological efficiency (PE), and partial factor productivity (PFP) are usually used to characterize the fertilizer use efficiency [1,28]. ARE, also known as apparent efficiency, refers to the percentage of applied fertilizer nutrients absorbed by crops in the current season [1,19]. It has been previously reported that the NARE for RZF in rice increased by 11.6 percentage points compared with the farmer fertilizer practice (three splits of $\mathrm{N}$ fertilizer) [11,12]. Wang et al. [7,17] also showed that the NUE of slow-release fertilizer by single application as base fertilizer on summer maize was increased by $4-5$ percentage points compared with a single application of urea. The improvement of NUE in RZF of summer maize in this study may have occurred because the $\mathrm{N}$ fertilizer applied in the root zone was deeply applied and better matched with the distribution of the root system, effectively improving the absorption of $\mathrm{N}$ by roots [11,13]. Compared with the split surface broadcasting, the proportion of $\mathrm{N}$ absorbed by rice from the applied urea under deep placement was increased by $62 \%$ [21]. Compared with SSB, the ${ }^{15} \mathrm{~N}$ recovery efficiency for RZF in summer maize was increased by 13 to $20 \%$ [13]. The RZF established a root zone and a nonroot zone in soil; the nonroot zone of RZF is the key area in which nutrients are supplied and intercepted, so as to minimize the nutrient losses [19]. The N loss in one-time RZF of summer maize was significantly decreased by 11 to $24 \%$ compared with that in split-surface broadcasting [20]. Moreover, deep application of $\mathrm{N}$ in the root zone significantly reduced the loss of $\mathrm{N}$ by ammonia volatilization, denitrification, and leaching [21,22,29]. Obviously, the RZF achieved higher NUE than the farmers' present fertilizer method (SSB) under the same rate of $\mathrm{N}$ application. Therefore, this study supports the conclusion that the RZF played an important role in improving NUE and reducing fertilizer losses, which provides a new approach for reducing $\mathrm{N}$ application rate and minimizing $\mathrm{N}$ loss. 


\subsection{Optimal Nitrogen Rate of RZF for Summer Maize}

Due to inappropriate fertilization methods and low NUE, overuse of $\mathrm{N}$ fertilizer is common in summer maize in China [3]. For example, the recommended rate of $\mathrm{N}$ fertilizer application for summer maize was $180 \mathrm{~kg} \mathrm{hm}^{-2}$, while the actual rate was $266 \mathrm{~kg} \mathrm{hm}^{-2}$ for the current practice in the North China Plain [4]. The average rate of $\mathrm{N}$ input for winter wheat-summer maize was up to $430 \mathrm{~kg} \mathrm{hm}^{-2}$ in the Huang-Huai-Hai Plain [30]. Moreover, the N rate for split application in summer maize was $310 \mathrm{~kg} \mathrm{hm}^{-2}$ in the vertisol soil of Anhui province, whereas the NUE in maize was only $23 \%$ [6]. Excessive $\mathrm{N}$ application resulted in a large amount of $\mathrm{N}$ losses in forms such as surface runoff, ammonia volatilization, nitrate leaching, and denitrification, thus causing serious ecological and environmental problems $[1,28,31,32]$. Therefore, on the basis of ensuring high yield, reducing $N$ rate and minimizing $\mathrm{N}$ loss is one of the important research directions in agricultural sustainability. In 2015, the Chinese Ministry of Agriculture issued the "Zero Increase Action Plan" to improve fertilization methods, increase fertilizer use efficiency, reduce fertilizer usage, and promote sustainable agricultural development [11]. In this study, on the basis of considering the price of maize grain and $\mathrm{N}$ fertilizer, the optimal economic $\mathrm{N}$ rate for RZF was $266.5-297.3 \mathrm{~kg} \mathrm{hm}^{-2}$, which reduced $\mathrm{N}$ fertilizer application by $14 \%$ compared with the SSB. Furthermore, there was no significant difference in the grain yield under the $\mathrm{N}$ rate of $180 \mathrm{~kg} \mathrm{hm}^{-2}$, while the NARE was significantly increased, compared with the maximum yield of the $\mathrm{N}$ rate $\left(275.8\right.$ and $309.7 \mathrm{~kg} \mathrm{hm}^{-2}$ ).

The $\mathrm{N}$ use of the maximum yield was usually much higher than the optimal $\mathrm{N}$ rate. However, for reducing $\mathrm{N}$ use and minimizing the environmental costs, the target yield was lower than the maximum yield [33]. The present study area belongs to a high-yield maize field in China [13]. According to the target yield of summer maize in this study area of 7.5-9.0 Mg hm${ }^{-2}$, combined with the $\mathrm{N}$ accumulation in grain of $127-170 \mathrm{~kg} \mathrm{hm}^{-2}$, NUE, and the balance of $\mathrm{N}$ in soil, this study concluded that the optimal $\mathrm{N}$ fertilization rate for summer maize in the vertisol soil of Anhui province was $180-225 \mathrm{~kg} \mathrm{hm}^{-2}$ for one-time RZF. This $\mathrm{N}$ fertilization rate not only ensured the high yield of summer maize but also realized high NUE and reduced the risk of $\mathrm{N}$ loss in farmland. However, more attention and further research should be carried out to investigate the potential capacity for one-time RZF to reduce chemical fertilizer and increase fertilizer use efficiency in the future. This analysis should clarify the role of RZF in the reduction of fertilizer application and the realization of the goal of zero increase of chemical fertilizer.

\section{Conclusions}

In summary, the RZF increased the grain yield of summer maize by $4 \%$ compared with the SSB under the same rate of $\mathrm{N}$ application. Nitrogen fertilizer affected the grain yield of summer maize mainly by regulating the number of kernels per ear and 1000-seed weight. Under the same rate of $\mathrm{N}$ fertilizer, the NARE of RZF was increased by $18 \%$ (7.2 percentage points) relative to that of SSB. The optimal $\mathrm{N}$ fertilization rate for summer maize in the vertisol soil of Anhui province was $180-225 \mathrm{~kg} \mathrm{hm}^{-2}$ for one-time RZF, which can reduce chemical $\mathrm{N}$ fertilizer by $14 \%$. The RZF has great potential capacity for increasing NUE and reducing the amount of $\mathrm{N}$ application.

Author Contributions: C.J. and S.W. performed the experiments; C.J., H.W., and C.Z. designed the research; C.J., X.R., and D.L. collected and analyzed data, and wrote the paper; C.J. and X.R. revised the manuscript.

Funding: The study was financially supported by the Natural Science Foundation of Anhui Province (1708085MC54) and the Discipline Team Project of Anhui Academy of Agricultural Sciences (2019YL039).

Conflicts of Interest: The authors declare no conflict of interest.

\section{References}

1. Zhu, Z.L.; Jin, J.Y. Fertilizer use and food security in China. Plant Nutr. Fertil. Sci. 2013, 19, 259-273.

2. Cui, Z.L.; Chen, X.P.; Li, J.L.; Xu, J.F.; Shi, L.W.; Zhang, F.S. Effect of $\mathrm{N}$ fertilization on grain yield of winter wheat and apparent $\mathrm{N}$ losses. Pedosphere 2006, 16, 806-812. [CrossRef] 
3. Cui, Z.L.; Chen, X.P.; Zhang, F.S.; Xu, J.F.; Shi, L.W.; Li, J.L. Appropriate soil nitrate N content for a winter wheat/summer maize rotation system in North China Plain. Chin. J. Appl. Ecol. 2007, 18, 2227-2232.

4. Chen, X.; Cui, Z.; Fan, M.; Vitousek, P.; Zhao, M.; Ma, W.; Wang, Z.; Zhang, W.; Yan, X.; Yang, J.; et al. Producing more grain with lower environmental costs. Nature 2014, 514, 486-489. [CrossRef] [PubMed]

5. Li, S.K. Field Guide of Summer Maize in the Huang-Huai-Hai Plain; China Agricultural University Press: Beijing, China, 2011.

6. Zheng, X.B.; Zhou, J.; Cui, J.; Ma, C.; Fang, C.X. Effects of different fertilization treatments on yields and nitrogen utilization of winter wheat-summer maize rotation system in region along Huai River. Soils 2012, 44, 402-407.

7. Wang, Y.L.; Bai, Y.L.; Tang, J.F.; Liu, J.; Lu, Y.L.; Han, Y.L. Availability study of once quantitative fertilization in summer maize using fertilizer tablets. J. Plant Nutr. Fertil. 2016, 22, 1126-1132.

8. Jiang, C.; Wang, H.; Lu, D.; Zhou, J.; Wang, S.; Zu, C. Single fertilization of urea in root zone improving crop yield, nutrient uptake and use efficiency in summer maize. Trans. Chin. Soc. Agric. Eng. 2018, 34, 146-153.

9. Gao, Q.; Li, D.Z.; Wang, J.J.; Bai, B.Y.; Huang, L.H. Effects of single fertilization for spring maize. J. Maize Sci. 2007, 15, 125-128.

10. Zhang, J.; Xia, G.L.; Li, H.; Zhu, G.L.; Mou, X.L.; Wang, L.G.; Huang, C.C.; Jiang, Y.Q. Effect of single basal fertilization on $\mathrm{N}_{2} \mathrm{O}$ emissions in wheat and maize rotation system. J. Agro-Environ. Sci. 2016, 35, 195-204.

11. Liu, X.; Wang, H.; Zhou, J.; Hu, F.; Chen, Z.; Liu, Y. Effect of $\mathrm{N}$ fertilization pattern on rice yield, $\mathrm{N}$ use efficiency and fertilizer-N fate in the Yangtze River Basin, China. PLoS ONE 2016, 11, e0166002. [CrossRef] [PubMed]

12. Liu, X.; Ling, D.; Chen, Z.; Wang, H.; Zhou, J.; Liu, Y.; Zhu, D.; Yan, T. Effects and principle of root-zone one-time $\mathrm{N}$ fertilization on enhancing rice (Oryza sativa L.) N use efficiency. Soils 2017, 49, 868-875.

13. Jiang, C.; Lu, D.; Zu, C.; Shen, J.; Wang, S.; Guo, Z.; Zhou, J.; Wang, H. One-time root-zone N fertilization increases maize yield, NUE and reduces soil N losses in lime concretion black soil. Sci. Rep. 2018, 8, 10258. [CrossRef]

14. Jiang, C.; Lu, D.; Wang, S.; Zhou, J.; Zu, C.; Wang, H. Research on placement site of urea single application in summer maize. J. Agric. Sci. Technol. 2017, 19, 67-74.

15. López-Bellido, L.; López-Bellido, R.J.; Redondo, R. Nitrogen efficiency in wheat under rainfed Mediterranean conditions as affected by split nitrogen application. Field Crops Res. 2015, 94, 86-97. [CrossRef]

16. Jiang, C.; Lu, D.; Zu, C.; Zhou, J.; Wang, H. Root-zone fertilization improves crop yields and minimizes nitrogen loss in summer maize in China. Sci. Rep. 2018, 8, 15139. [CrossRef]

17. Wang, Y.L.; Li, C.H.; Tan, J.F.; Han, Y.L.; Zhang, X. Studies on plant nitrogen accumulation characteristics and the effect of single application of base fertilizer on super-high-yield summer maize. Sci. Agric. Sin. 2010, 43, 3151-3158.

18. Ge, J.Z.; Zhan, M.; Zhao, M.; Li, J.G.; Li, S.Y.; Tian, S.Y. Effects of single basal fertilization on yield and nutrient use efficiencies of spring maize in the Middle Reaches of Yangtze River. J. Plant Nutr. Fertil. 2013, 19, 1073-1082.

19. Wang, H.; Zhou, J. Root-zone fertilization-A key and necessary approach to improve fertilizer use efficiency and reduce non-point source pollution from the cropland. Soils 2013, 45, 785-790.

20. Liu, T.Q.; Fan, D.J.; Zhang, X.X.; Chen, J.; Li, C.F.; Cao, C.G. Deep placement of nitrogen fertilizers reduces ammonia volatilization and increases nitrogen utilization efficiency in no-tillage paddy fields in central China. Field Crop Res. 2015, 184, 80-90. [CrossRef]

21. Yao, Y.; Zhang, M.; Tian, Y.; Zhao, M.; Zhang, B.; Zhao, M.; Zeng, K.; Yin, B. Urea deep placement for minimizing $\mathrm{NH}_{3}$ loss in an intensive rice cropping system. Field Crop Res. 2018, 218, 254-266. [CrossRef]

22. Cai, G.X.; Chen, D.L.; Ding, H.; Pacholski, A.; Fan, X.H.; Zhu, Z.L. Nitrogen losses from fertilizers applied to maize, wheat and rice in the North China Plain. Nutr. Cycl. Agroecosyst. 2002, 63, 187-195. [CrossRef]

23. Uhart, S.A.; Andrade, F.H. Nitrogen deficiency in maize: I. Effects on crop growth, development, dry matter partitioning, and kernel set. Crop Sci. 1995, 35, 1376-1383. [CrossRef]

24. Cao, S.B.; Zhang, J.W.; Dong, S.T.; Liu, P.; Zhao, B.; Yang, J. Effects of nitrogen rate and planting density on grain yield and nitrogen utilization efficiency of high yield summer maize. Plant Nutr. Fertil. Sci. 2012, 18, 1343-1353.

25. Wang, K.; Wang, K.R.; Wang, Y.H.; Zhao, J.; Zhao, R.L.; Wang, X.M.; Li, J.; Liang, M.X.; Li, S.K. Effects of density on maize yield and yield components. Sci. Agric. Sin. 2012, 45, 3437-3445. 
26. Li, M.; Yang, K.J.; Liu, G.; Xu, J.X.; Liu, J.H. Study on high-yield components of maize in cold region. J. Northeast Agric. Univ. 2005, 36, 553-555.

27. Cai, H.; Yuan, J.; Liu, J.; Yan, X.; Zhang, H.; Liang, Y.; Ren, J. Optimal nitrogen application rate and nitrogen requirement characteristics in spring maize under high planting density condition. Sci. Agric. Sin. 2017, 50, 1995-2005.

28. Zhang, F.; Wang, J.; Zhang, W.; Cui, Z.; Ma, W.; Chen, X.; Jiang, R. Nutrient use efficiencies of major cereal crops in China and measures for improvement. Acta Pedol. Sin. 2008, 45, 915-924.

29. Rochette, P.; Angers, D.A.; Chantigny, M.H.; Gasser, M.; MacDonald, J.D.; Pelster, D.E.; Bertrand, N. Ammonia volatilization and nitrogen retention: How deep to incorporate urea? J. Environ. Qual. 2013, 42, 1635-1642. [CrossRef]

30. Ju, X.T.; Gu, B.J. Status-quo, problem and trend of nitrogen fertilization in China. J. Plant Nutr. Fertil. 2014, 20, 783-795.

31. Sharma, L.K.; Bali, S.K. A review of methods to improve nitrogen use efficiency in agriculture. Sustainability 2018, 10, 51. [CrossRef]

32. Zhao, H.; Li, X.; Jiang, Y. Response of nitrogen losses to excessive nitrogen fertilizer application in intensive greenhouse vegetable production. Sustainability 2019, 11, 1513. [CrossRef]

33. Wang, G.L.; Ye, Y.L.; Chen, X.P.; Cui, Z.L. Determining the optimal nitrogen rate for summer maize in China by integrating agronomic, economic, and environmental aspects. Biogeosciences 2014, 11, 3031-3041. [CrossRef]

(C) 2019 by the authors. Licensee MDPI, Basel, Switzerland. This article is an open access article distributed under the terms and conditions of the Creative Commons Attribution (CC BY) license (http://creativecommons.org/licenses/by/4.0/). 